\title{
Social Loafing in Group Work: Prevalence, Contributing Factors, and Consequences in Madda Walabu University
}

\author{
Zenebe Demissie Tekle* \\ Psychology Department, Debre Berhan University, PO box 247, Debre brhan, Ethiopia \\ Esa Aliye Sado \\ Psychology Department, madda Walabu University, PO box 247
}

\begin{abstract}
The research is financed by Madda Walabu University
Abstract

The general objective of this research was to see the prevalence, contributing factors and consequences of social loafing in MWU. Both quantitative and qualitative methods were employed to achieve the research objectives. The participants were: $2772^{\text {nd }}$ and $3^{\text {rd }}$ year students. The participants were selected using stratified random sampling technique. To collect data regarding variables under the study, self-report (rating) questionnaire adapted from Jassawalla, Malshe, and Shashittal (2008) and interview were used. The results of percentage and frequency reveled that social loafing is prevalent in group works. Stepwise multiple regression indicated that some variables such as, evaluation methods, lack of skills, group size, and laziness have significant contribution to social loafing. The frequency and percentage result indicated that there are negative consequences of social loafing. Based on the findings, the researchers recommended that stakeholders have great responsibility for effectiveness of student group work.
\end{abstract}

Keywords: Group Size, Group Work, Lack of Skills, Laziness, Social Loafing

DOI: $10.7176 /$ RHSS/10-19-02

Publication date:October $31^{\text {st }} 2020$

\section{Backgroud}

Social loafing has been found on a variety of tasks, including work-related tasks, physical tasks, cognitive tasks, and evaluative tasks. In academic settings social loafing has been found, for example, on tasks that require generating ideas and working on group papers (Karau, 2012).

Research findings (Karau and Williams, 1993, 2001; and Dhashendra, 2011) recognized in any student group work, social loafing is exhibited by certain members being repeatedly absent, being disengaged and fulfilling their work commitments inadequately or not at all (Latane, Williams, \& Harkins, 1979).

The perception that social loafing exists in group work contexts is universal among university students and undermines the potential effectiveness of group work (Piezon \& Ferree, 2008). For example, in McCorkle, Reardon, Alexander, Kling, Harris, \& Iyer's (1999) study, 65 percent of surveyed students reported that they had encountered social loafing within university-level group work. Similarly, in Hall \& Buzwell's (2012) study 61 percent of the respondents reported the existence of social loafing in group work. Researches also indicated that the presence of social loafing reduces satisfaction in group work (Pfaff \& Huddleston, 2003), reduces group cohesion, and harms performance or output of a team (Schnake, 1991).

Social loafing is influenced by factors such as the degree to which group members' individual inputs can be identified and evaluated, the meaningfulness or personal relevance of the task, the degree to which each individuals inputs is unique and less redundant with those of other group members, group size (Latané, 1981; Karau, 2012; Kerr, 1989; Hindriks \& Pancs, 2001; and Chidambaram \& Tung, 2005 ), evaluation methods such as comparing groups with each other (Hurley \& Allen, 2007), differing style among group members, the method of group formation, division of tasks among group members, and task difficulty (Hall \& Buzwell, 2012; and Karau \& Williams, 2001).

Deeter-Schmelz et al. (2002) found that as the size of the group increases, the number of incidents of participation per member decreases. Hechter (1987) also found that increased group size inhibits the ability of team members to both monitor and encourage each other. Aggarwal and O'Brien (2008) and Maiden and Perry's (2011) study also found that smaller group sizes reduced incidences of social loafing.

Social loafing is said to disappear when participants believe that their individual effort can be observed, measured or evaluated, resulting in them being held accountable for their contribution (Brooks \& Ammons, 2003; Thompson \& Thornton, 2007). For example, a perception that the distribution of rewards is fair has been shown to be negatively related to social loafing (Liden et al., 2004).

Another contributing factor to social loafing is the method of group formation (Hall \& Buzwell, 2012; Manhenthiran \& Rouse 2000; Pieterse and Thompson, 2010). Manhenthiran and Rouse (2000) discovered that when students were permitted to pair up with at least one friend in a learning group, they were more likely to put forth more effort than students who were assigned to random groups. Bacon et al. (1999) and Strong and Anderson 
(1990) also argued for self-selected group to reduce social loafing. However, others indicate some negative consequences of self-selection including groups being homogenous and lacking diversity and groups possessing inadequate skill sets among their group members. Similarly it is reported that random team assignment is unfair (Bacon et al., 1998) and unpredictable. A study that compared the influence of self-selected and randomly assigned teams on social loafing, found no significant differences between the two methods of team formation (Aggarwal \& O’Brien, 2008).

Researchers Karau \& Williams, (2001) found that when people are given a difficult task, they work on it just as hard in a group as they would individually and social loafing decreases.

In general, researches (e.g., Hall \& Buzwell, 2012) showed that social loafing is the greatest concern across all disciplines. However, despite most higher education instructors who are complaining about social loafer in group works or projects, research in the area of social loafing received comparatively less attention in Ethiopia. The relatively spare research on social loafing in higher education settings has left room for further research. First, much of the researches (Bacon, Stewart, \& Stewart-Belle, 1999; Karau \& Williams, 2001, Hall \& Buzwell, 2012) have been conducted on western countries. Second, some of the findings, for example, on the effect of types of group formation and evaluation methods on social loafing have been contradictory. Some studies (Brooks \& Ammons, 2003; Thompson \& Thornton, 2007) reported a reduction in social loafing as a result of evaluation methods. However, Karau (2012) suggested that evaluation is not always sufficient to reduce or eliminate social loafing. Concerning group formation, some research (Manhenthiran \& Rouse, 2000; Bacon et al. 1999; Strong \& Anderson, 1990) argue that self-formed group reduces social loafing while others ((Bacon, Stewart, \& StewartBelle, 1999) are against the use of self-formed group arguing that it lacks diversity.

Therefore, the current study helps us understand how group size, teacher's evaluation methods of students' group work, types of group formation, task difficulty, lack of skills, and lack of motivation affects students' social loafing. It is hoped that this study will provide instructors and other concerned bodies with relevant information on the trend of social loafing, factors contributing to social loafing, and consequences of social loafing among higher education students and may indicate directions for intervention model they might make use of to reduce social loafing. The research aims at investigating the prevalence, contributing factors, consequences of social loafing in educational settings.

\section{Methods and Materials \\ Study Are}

The current study conducted in Madda Walabu University (MWU). Madda Walabu University is one of governmental university in Ethiopia which is located $430 \mathrm{~km}$ away from the capital city Addis Ababa. The university has different colleges and schools in it. The rationality of choosing this area was based on the researcher's observation that, at Madda Walabu University teachers have challenged to evaluate student's group work because of social loafers.

\section{Research Design}

The researchers employed mixed research design (both qualitative and quantitative methods) to explore the prevalence, contributing factors, and consequences of social loafing in group work among Madda Walabu University $2^{\text {nd }}$ and $3^{\text {rd }}$ year regular students.

\section{Participants}

The total population of this study was second and third year undergraduate regular students in Madda Walabu University in the year 2016/2017. According to Madda Walabu University registrar data, in 2016/2017, 5959 students are attending their education from the second year and above. To make our sample representative of the whole population, stratified random sampling was used. The stratification was based on year of study, department, and sex. The sample size for this study was determined by using Tabachnick and Fedell (2007) suggestion to determine sample size when using stepwise multiple regressions which suggested a case-to-IV ratio of 40 to 1 . Thus, the minimum sample size required for six predictors or independent variables is 240 . That is, 6 independent variables multiplied by 40 . Considering that the return rate of the questionnaire may not be $100 \%$, we distributed 400 questionnaires to students at their classroom. Out of 400 students, 312 (78\%) of them filled and returned the questionnaire. 35 of the returned questionnaire was excluded from the analyses because of missing values. Thus, the final analyses were made on a sample of 277 respondents.

\section{Measures}

The current instrument is adapted from Jassawalla, Malshe, and Shashittal (2008). The survey includes items that could measure the prevalence, contributing factors, and consequences of social loafing in a group work. It also included items that could measure what the team did to the social loafer, and what they recommend the professor to do. This survey of social loafing is on a 5-point Likert type scales which indicates 1 (strongly disagree), 2 
(disagree), 3 (neither agree nor disagree or undecided), 4 (agree), and 5 (strongly agree). Jassawalla, Malshe, and Shashittal (2008) reported the Cornbrash's alpha of the four subscales ranging from 0.654 to 0.821 in their original paper. The items are randomized in the questionnaire to minimize the impact of order bias. A high score on the instrument indicates a high degree of social loafing, the variables under the study contribute high to social loafing, and the negative impact of social loafing is high. Pilot test result revealed that the Cornbrash's alpha of the subscales of evaluation methods, laziness, group formation methods, and task difficulty were .66, .57, .82 and .51 respectively. Test-retest reliability for group size and lack of skills were 0.77 and 0.81 respectively. The interview questions are semi-structured and have probing words. It is prepared by the researchers based on the Jassawalla, Malshe, and Shashittal (2008) Survey of Social Loafing in a Classroom Teams.

\section{Data Analysis}

The quantitative data was organized, tabulated and analyzed by using, frequency, percentage, multiple regression, and t-test. In addition to this, qualitative data was analyzed by using narration in the way it supplements the quantitative analysis. Responses from the interviewee were analyzed thematically.

\section{Ethical Consideration}

Before distributing the questionnaires to the respondents the researchers asked the participants about their willingness to fill the questionnaires and permission to be interviewed. So based on this, the respondent was signed the consent form.

\section{Results}

\section{Prevalence of Social Loafing in Group Work}

Table 1. Summery result of prevalence of social loafing in group work

\begin{tabular}{|c|c|c|c|c|c|c|c|c|c|c|}
\hline \multirow[t]{2}{*}{$\begin{array}{l}\text { Items } \\
\text { Some members of my groups: }\end{array}$} & \multicolumn{2}{|c|}{$\begin{array}{l}\text { S. } \\
\text { Disagree }\end{array}$} & \multicolumn{2}{|c|}{ Disagree } & \multicolumn{2}{|c|}{ Neither } & \multicolumn{2}{|c|}{ Agree } & \multicolumn{2}{|c|}{ S. Agree } \\
\hline & $\mathrm{Fq}$. & $\%$ & Fq. & $\%$ & Fq. & $\%$ & Fq. & $\%$ & Fq. & $\%$ \\
\hline Are contributing less than I exp & 38 & 13.6 & 61 & 21.8 & 29 & 10.4 & 86 & 30.7 & 63 & 22.5 \\
\hline Do not do their share of work & 42 & 15 & 78 & 27.9 & 32 & 11.4 & 79 & 28.2 & 46 & 16.4 \\
\hline $\begin{array}{l}\text { Spend less time on the group work if others } \\
\text { are present to handle the job. }\end{array}$ & 47 & 16.8 & 49 & 17.5 & 28 & 10 & 95 & 33.9 & 58 & 20.7 \\
\hline $\begin{array}{l}\text { Avoid helping others finish the group work as } \\
\text { much as possible. }\end{array}$ & 64 & 22.9 & 57 & 20.4 & 39 & 13.9 & 70 & 25 & 47 & 16.8 \\
\hline $\begin{array}{l}\text { Are less likely to make practical contribution } \\
\text { to group work if other members are available } \\
\text { to do this. }\end{array}$ & 46 & 16.4 & 73 & 26.1 & 40 & 14.3 & 69 & 24.6 & 49 & 17.5 \\
\hline Did poor quality work & 62 & 22.1 & 65 & 23.2 & 51 & 18.2 & 59 & 21.1 & 40 & 14.3 \\
\hline $\begin{array}{l}\text { Often miss, or arrive late at group meetings } \\
\text { without prior notice to the whole group or the } \\
\text { group leader. }\end{array}$ & 60 & 21.4 & 58 & 20.7 & 37 & 13.2 & 71 & 25.4 & 51 & 18.2 \\
\hline Was mostly silent during the group meetings. & 60 & 21.4 & 54 & 19.3 & 29 & 10.4 & 72 & 25.7 & 62 & 22.1 \\
\hline $\begin{array}{l}\text { Involved in conversations not related to the } \\
\text { group work. }\end{array}$ & 75 & 26.5 & 47 & 16.8 & 30 & 10.7 & 63 & 22.5 & 62 & 22.1 \\
\hline Came poorly prepared to the group meetings. & 51 & 10.2 & 47 & 16.8 & 29 & 10.4 & 78 & 27.9 & 72 & 25.7 \\
\hline
\end{tabular}

Table 1 show that $30.7 \%$ of students indicated that some members of their groups are contributing less than they expected. More over $28.2 \%$ of students indicated that some members of their groups do not do their share of work. In addition, $33.9 \%$ of students revealed that some members of their groups spend less time on the group work if others are present to handle the job. $25 \%$ of students indicted that some members of their groups avoid helping others finish the group work as much as possible. $24.6 \%$ of students agreed that some members of their groups are less likely to make practical contribution to group work if other members are available to do this. $25.7 \%$ of the students revealed that some members of their group were mostly silent during the group meetings. And also, $27.9 \%$ of students agreed with some members of their group came poorly prepared to the group meeting. At face value these results may already indicated the prevalence of social loafing amongst the respondents. In addition to this the qualitative results support the above quantitative findings as the following: Some interviewee's declared that they did not like group works because there are so many dependent (free-riders) in the group. They witnessed like "...this may waste our time to do our efforts strictly". This indicated that there is social loafing in group works. In accordance to the first ideas, they declared that:

"In our group works some members let alone to contribute to group work, they have no concern about the group works, some others engaged in conversation with others out of the agenda of the group works, 
some others use their cell phone or chat with Facebook rather than participating in the group works. While we ask them to contribute a piece of paper, they can't respond properly". In our group works, most of a time a burden is in one individual others are free-rider. Rather than contributing their effort of knowledge simply they give money for the group works. Those who came from poor families may try to do with the group members, but they have not enough skills and bits of knowledge how to do group works. However, some students or members are presented at the time of group works, but have not contributing anything to the group works. There are so many free-riders in our group which expected everything from the group leaders. They can't take responsibilities by themselves rather they transfer to group leaders. Some others came without any contribution and haven't commitments. In addition to this, they haven't interested to come earlier or they may come late (they are late comers). If we give responsibilities to them they came with poor qualities of work".

\section{The Major Determinant Factors that Contribute to Social Loafing}

A stepwise multiple regressions were conducted to evaluate whether all the six variables were necessary to social loafing. At step one of the analysis evaluation methods entered into the regression equation and was significantly related to Social loafing, $\mathrm{F}(1,267)=91.855, \mathrm{p}<.000$. The multiple regression coefficients was .256 , indicating approximately $25.6 \%$ (25.3\% adjusted) of the variance in social loafing could be accounted for by Evaluation method scores. At step 2 of the analysis, Lack of skills entered into the regression equation and was significantly related to Social loafing, $\mathrm{F}(2,266)=61.834, \mathrm{p}<.000$. The multiple regression coefficient was.317, indicating approximately $31.7 \%$ (31.2\% adjusted) of the variance of social loafing could be accounted for by Evaluation methods and Lack of skills scores. At step 3 of the analysis, Group size entered into the regression equation and was significantly related to Social loafing, $\mathrm{F}(3,265)=45.968, \mathrm{p}<.000$. The multiple regression coefficient was.342, indicating approximately $34.2 \%$ (33.5\% adjusted) of the variance of social loafing could be accounted for by Evaluation methods, Lack of skills scores, and Group size. At step 4 of the analysis, Laziness (lack of motivation) entered into the regression equation and was significantly related to Social loafing, $\mathrm{F}(4,264)=36.844, \mathrm{p}<.000$. The multiple regression coefficient was.358, indicating approximately $35.8 \%$ (34.9\% adjusted) of the variance of social loafing could be accounted for by Evaluation methods, Lack of skills scores, Group size, and Laziness (Lack of motivation). Team formation methods, Task difficulty, and Lack of interest in tasks did not enter into the equation. That is, none of these three variables adds further prediction.

Table 2. Stepwise Multiple Regression

Regression Coefficients

\begin{tabular}{llcc}
\hline Variable/Model & B & SE B & $\beta$ \\
\hline Evaluation methods & & & .271 \\
Lack of skills & .680 & .443 & $.235^{* *}$ \\
Group size & 1.594 & .381 & $.167^{* *}$ \\
Laziness (lack of motivation) & 1.101 & .257 & $.170^{*}$
\end{tabular}

$* p<.05 . * * p<.01$.

Looking at the regression coefficients (Table 2), all the four variables (evaluation methods, lack of skills, group size, and laziness) were independently significant in predicting social loafing. The standardized slopes (i.e., $\beta$ coefficients) indicate that evaluation methods $(\beta=.178, \mathrm{t}=2.512, \mathrm{p}<.05)$, lack of skills $(\beta=.235, \mathrm{t}=3.599$, $\mathrm{p}<.001$ ), group size $(\beta=.167, \mathrm{t}=2.890, \mathrm{p}<.01)$, and laziness (lack of motivation) $(\beta=.170, \mathrm{t}=2.564$, $\mathrm{p}<.05$ ), were independently statistically significant in predicting job satisfaction. Of the four variables lack of skills had the largest effect $(\beta=.235)$ on the students' social loafing. 


\section{Consequences of Social Loafing in Group Work}

Table 3: Summery Result of Consequences of Social Loafing in Group Work

\begin{tabular}{|c|c|c|c|c|c|c|c|c|c|c|}
\hline \multirow{2}{*}{$\begin{array}{l}\text { Items: } \\
\text { As a result of social loafing: }\end{array}$} & \multicolumn{2}{|l|}{ SD } & \multicolumn{2}{|l|}{ DA } & \multicolumn{2}{|l|}{$\mathbf{N}$} & \multicolumn{2}{|l|}{$\mathbf{A A}$} & \multicolumn{2}{|l|}{ SA } \\
\hline & Fq. & $\%$ & Fq. & $\%$ & Fq. & $\%$ & Fq. & $\%$ & Fq. & $\%$ \\
\hline $\begin{array}{l}\text { The group took longer than expected to } \\
\text { complete its tasks }\end{array}$ & 29 & 10.4 & 48 & 17.1 & 32 & 11.4 & 89 & 31.8 & 78 & 27.9 \\
\hline $\begin{array}{l}\text { Other group members had to do more than } \\
\text { their share of work. }\end{array}$ & 41 & 14.6 & 30 & 10.7 & 40 & 14.3 & 88 & 11.7 & 77 & 27.5 \\
\hline $\begin{array}{l}\text { Other group members were stressed, } \\
\text { frustrated and angry. }\end{array}$ & 51 & 18.2 & 44 & 15.7 & 52 & 18.6 & 79 & 28.2 & 50 & 17.9 \\
\hline $\begin{array}{l}\text { The work had to be re-assigned to other } \\
\text { members of the group. }\end{array}$ & 64 & 22.9 & 40 & 14.3 & 40 & 14.3 & 71 & 25.4 & 60 & 21.4 \\
\hline $\begin{array}{l}\text { The group's final presentation was not as high } \\
\text { quality as that of other groups. }\end{array}$ & 52 & 18.6 & 46 & 16.4 & 41 & 14.6 & 75 & 26.8 & 59 & 21.1 \\
\hline The group missed deadlines. & 48 & 17.1 & 39 & 13.9 & 36 & 12.9 & 78 & 27.9 & 72 & 25.7 \\
\hline The group lacks satisfaction. & 52 & 18.6 & 38 & 13.6 & 34 & 12.1 & 86 & 30.7 & 64 & 22.9 \\
\hline Members received unfair grade result. & 59 & 21.1 & 41 & 14.6 & 34 & 12.1 & 73 & 26.1 & 68 & 24.3 \\
\hline Members received poor grade. & 48 & 17.1 & 42 & 15 & 37 & 13.2 & 74 & 26.4 & 74 & 26.4 \\
\hline Groups divided and they lack unity. & 42 & 15 & 37 & 13.2 & 36 & 12.9 & 73 & 26.1 & 86 & 30.7 \\
\hline Their group performances are decreas & 49 & 17.5 & 32 & 11.4 & 24 & 8.6 & 82 & 29.3 & 89 & 31.8 \\
\hline
\end{tabular}

Table 3 shows that $31.8 \%$ of students indicated that as a result of social loafing, their group performances are decreased. More over $30.7 \%$ of students indicated that as a result of social loafing groups are divided and they lack unity. In addition, $27.9 \%$ of students revealed that as a result of social loafing the group took longer than expected to complete its tasks. $27.5 \%$ of students indicted that as a result of social loafing other group members had to do more than their share of work. $26.4 \%$ of students agreed that as a result of social loafing members received poor grade. $25.7 \%$ of the students revealed that as a result of social loafing the group missed deadlines. And also, 24.3\% of students agreed with as a result of social loafing members received unfair grade result.

\section{Discussion}

In this study the prevalence and magnitude of social loafing that reveals social loafing was found in group work. These results are consistence with the finding of a meta-analytic synthesis by Karau and Williams $(1993,2001)$ and a research by Dhashendra (2011), social loafing was found consistently across all the studies and the evidence indicated that individuals tended to engage in the phenomenon when working collectively. In a student team, this is exhibited by certain members being repeatedly absent, being disengaged and fulfilling their work commitments inadequately or not at all (Latane, Williams, \& Harkins, 1979).

This study investigated the effect of evaluation methods, lack of skills, group size, and laziness on social loafing in group work. The results indicate that the four variables (evaluation methods, lack of skills, group size, and laziness) were important in predicting social loafing independently and jointly. Evaluation methods, lack of skills, group size, and laziness positively correlated with social loafing.

This result supports the claim that social loafing disappears when participants believe that their individual effort can be observed, measured or evaluated, resulting in them being held accountable for their contribution (Thompson \& Thornton, 2007). That is, the potential evaluation of individual contributions to team-work has a particularly powerful impact in ensuring that each team member does a fair share of collaborative tasks (Brooks \& Ammons, 2003). The qualitative data obtained through interview also supported the contribution of teachers' evaluation system for the occurrence of social loafing. One of the interviewee described the effect of teachers' evaluation on group work as "If a teacher evaluates each individual effort or gives values for those who have great contribution in the group works, the social loafing may decrease. This is in line with previous studies that provide support for positive relationship between not evaluating individual contribution in group work and social loafing (Brooks \& Ammons, 2003; Hurley \& Allen, 2007; Liden et al., 2004; Thompson \& Thornton, 2007). In addition to this, if a teacher informs the students that contents in the assignment or group works may be incorporated in their exam each member of the group tries to participate in the group works." This finding result is supported by Hurley \& Allen, (2007) who suggested that, evaluation in a group setting informs the quality of a person's work and reduces social loafing.

In our finding, lack of skills is also another variable contributing to social loafing. Individuals who lack skill view their effort as being too small to make a difference given "others" who can contribute; thus, they withdraw effort from the group (Chidambaram \& Tung, 2005). As described by respondents in group works, those group members who believe they lack skills simply contribute money or papers rather than contributing their effort for the group works. This is consistent with the finding of Chidambaram \& Tung, (2005). These findings indicated that the more individual contributions are assessed in group works, students lack skills to contribute to group work. 
Similarly, in group work, social loafing occur when strong team members excluding the contributions of weaker members (Pieterse \& Thompson, 2010).

As expected a positive correlation was found between group size and social loafing in the current study. This may be explained by Dispensability of Effort Theory. According to Dispensability of Effort Theory, during certain tasks, members might be reluctant to exert effort if they have an idea that their contributions are redundant or unneeded compared with those of other group members, or are immaterial to group performance (Hart, Karau, Stasson \& Kerr, 2004). This theory seems to relate to group size. In other words, in larger groups, individuals generally believe they make less of a difference. That is, as the size of the group increases, the number of incidents of participation per member decreases (Deeter-Schmelz et al. 2002). Individuals may feel their contributions are more essential to the success of the process when they work in smaller groups than when they work in larger groups (Hindriks \& Pancs, 2001; Belanger, Watson-Manheim \& Jordan, 2002; Hindriks \& Pancs, 2001; Jones, 1984; Karau, 2012; \& Latane, 1981).

There are also, positive correlation between laziness or lack of motivation and social loafing. Karau, (2012) suggested that the effects of the presence of others on task performance are mediated by a set of cognitive and motivational variables. Changes in group size simultaneously influence several motivational and cognitive variables that can then affect task performance. As described by interviewed respondents in group works "some members of the group let alone to make contribution to the group work, they have no concern about the group works; some others engaged in conversation with others out of the agenda of the group works, some others use their cell phone or chat with Facebook, some others simply they give money, and some others expected everything from the group leaders rather than participating in the group works. This is in line with the finding of Paulus (1983) cited in Griffith, Fichman, \& Moreland, 1989).

This study also investigated the consequences of social loafing in group work. At face value in the results may already indicated the consequences of social loafing amongst the respondents. The experiences of students regarding the consequences of social loafing was assessed by asking respondents to respond to established dimensions and aspects of the consequences of social loafing using a 1 to 5 point Likert scale. The results were processed using descriptive statistics (Table 3). In addition to this the qualitative results support the above quantitative findings. Some interviewee's declared that 'because of the presences of a social loafer, we may waste our time by waiting for them for a long time and the deadline may be left. It decreases our group cohesiveness, it takes a long time to finish, and it may lack the contribution of new ideas. We may miss knowing what expected to know. It may be dangers for the social loafers because they can't get knowledge if the exam incorporated the issues from the given group works'. This is in line with previous studies that provide support for consequences of social loafing such as perceived unfairness of project grade (Beatty et al., 1996), groups splitting and lack of cohesion, and decreased group performance (Brooks and Ammons, 2003; King \& Behnke, 2005; Latane, 1979).

\section{Conclusion}

Based on the major findings of the study, the following conclusions are drawn:

Second and third year MWU students have encountered to social loafing. The result indicated that prevalence rate of social loafing has higher and consistent with other research findings. This indicated that social loafing has impact on students group work in higher education.

In different research findings there are numerous factors that contribute for the increment of social loafing. Among those factors evaluation system, group size, lack of skill, and laziness are considered as the major contributing factors.

The existence of social loafing has its own impact on the general educational systems specifically in the learning-teaching process. The current research result witnessed, the presence of social loafing in higher educational institute (MWU) has the following major consequences:

- $\quad$ Lack of satisfaction with group members

- Unfair grading of the student result

- Group split and lack of cohesion

In addition to this, because of the presences of a social loafer, students waste their time by waiting for others for a long time and missed the deadline for submitting the assignment. This decreases group cohesiveness, takes a long time to finish the group work, and the may not generate new ideas. The student may get knowledge that they should get of group work. It may be dangers for the social loafers because they can't get knowledge if the exam incorporated the issues from the given group works.

\section{Recommendation}

Based on the research result the following recommendations are drown:

- Teachers have to play a role to reduce the magnitude and prevalence rate of the problem by applying theoretical suggested ways and research finding indicators.

- Before, during and after each class the instructors should have given orientation for students about the 
effect of social loafing and the measure will be taken.

- Teachers, parents, college or university coordinators should follow up and guiding students' group work.

- The instructors should evaluate students in fair manner.

- Teachers or instructors; give group work which is relevant, easily accessible, and related to the course.

- The group members and group leaders should not resist or tolerate those who did not give their contribution and not participate equally in their group work.

- All group members should participate equally and avoid domination.

- Teachers and parents; by any means motivate students to do their best and to show their ability in group work.

- Instructors should give clues, trained, show ways, practiced etc. for students to improve their lack of skills.

- Instructors should manage the group size based on the number of students in the class room.

\section{References}

Aggarwal, P. and O'Brien, C., 2008. Social loafing on group projects: Structural antecedents and effect on student satisfaction. Journal of Marketing Education, 30(3), 25-264.

Bacon D. R. Stewart K. A. and Silver W. S., 1999. Lessons from the best and worst student team experiences: How a teacher can make the difference. Journal of Management Education 23(5): 467-88.

Bacon, D. R., Stewart, K. A., \& Stewart-Belle, S. (1998). Exploring predictors of student team project performance. Journal of Marketing Education, 20(1), 63-71.

Belanger, F. Watson-Manheim, M. B. and Jordan D. H. J., 2002.Aligning IS research and practice: A research agenda for virtual work. Inform. Resources Management 15(3):48-70 CrossRef.

Brooks, C. M. and Ammons, J. L., 2003. Free riding in group projects and the effects of timing, frequency, and specificity of criteria in peer assessments. Journal of Education for Business, 78, 268-272.

Chidambaram, L. and Tung, L.L., 2005. Is Out of Sight, Out of Mind? An Emperical Study of Social Loafing in Technology-Supported Groups. Information Systems Research, 16(2), 149-168. Retrieved on June 23 ${ }^{\text {rd }} 2008$, from Informs.

Deeter-Schmelz, D. R. Kennedy, K. N. and Ramsey, R. P., 2002.Enriching Our Understanding of Student Team Effectiveness. Journal of Marketing Education, 24(2), 114-124.

Dhashendra Naicker (2011). The Prevalence and Magnitude of Social Loafing In an Organizational Setting.

Hall, D. and Buzwell, S., 2012. The problem of free-riding in group projects: Looking beyond social loafing as reason for non-contribution. Learning in Higher Education. 14: 37-49.

Hart J. Karau S. Stasson M. and Kerr N., 2004. Achievement Motivation, Expected Coworker Performance and Collective Task Motivation. Journal of Applied Social Psychology.34 (5); 984- 1000.

Hechter, M., 1987.Principles of group solidarity. Berkeley: University of California Press.

Hindriks, J. and Pancs, R., 2001. Free riding on altruism and group size.Retrieved November 24, 2004, from http:/www.econ.qmul.ac.uk/Papers/docs/wp436.pdf.

Hurley \& Allen, 2007.The Free-Rider Problem in Group Work; An empirical research among students of the secondary vocational education, the higher professional education and university.

Jassawalla, A. R. Malshe, A. Sashittal, H., 2008. Student Perceptions of Social Loafing in Undergraduate Business Classroom Teams.Decision Sciences Journal of Innovative Education, 6(2), 403-426.

Jones, G.R., 1984. Task visibility, free riding, and shirking: Explaining the effect of structure and technology on employee behavior. Academy of Management Review, 9, 684-695.

Karau, S.J., 2012. Social Loafing (and Facilitation). Southern Illinois University, Carbondale, IL, USA, Elsevier Inc.

Karau, S. J. and Williams, K. D., 1993. Social loafing: A meta-analytic review and theoretical integration. Journal ofPersonality \& Social Psychology, 65(4), 681-706.

Karau, S. J and Kipling D. Williams, K. D., 2001. Social Loafing: Research Findings, Implications, and Future Directions, Cambridge University Press. American Psychological Society, 4(5),

Latane, B., 1981. The psychology of social impact. American Psychologist, 36, 343-356.

Latane, B. Williams, K. and Harkins, S., 1979. Many Hands Make Light the Work: The Causes and Consequences of Social Loafing. Journal of Personality and Social Psychology, 37(6), 822-832.

Liden, R. C. Wayne, S. J. Jaworski, R. A. and Bennett, N., 2004. Social loafing: A field investigation. Journal of Management, 30(2), 285-304.

Mahenthiran, S. and Rouse, P. M., 2000.The impact of group selection on student performance and satisfaction. The International Journal of Educational Management, 14(6), 255-264.

Maiden, B. and Perry, B., 2011. Dealing with free-riders in assessed group work: results from a study at a UK 
university. Assessment \& Evaluation in Higher Education, 36(4), 451-464.

McCorkle, D. E. et al., 1999. Undergraduate Marketing Students, Group Projects, and Teamwork: The Good, the Bad, and the Ugly? Journal of Marketing Education, 21(2), 106-117.

Pfaff, E. and Huddleston, P., 2003. Does it matter if I hate teamwork? What impacts student attitudes toward teamwork. Journal of Marketing Education, 25, 37-45.

Piezon, S. L., \& Ferree, W. D. (2008). Perceptions of social loafing in online learning groups: A study of public university and U.S. naval war college students. International Review of Research in Open and Distance Learning, 9(2), 1-17.

Pieterse, V., \& Thompson, L., 2010.Academic Alignment to Reduce the Presence of "Social Loafers" and "Diligent Isolates" in Student Teams. Teaching in Higher Education, 15(4), 355-367.

Schnake, M.E., 1991. Equity in Effort: The 'sucker effect' in co-acting groups. Journal of Management, 17(1), 4156.

Strong, James T. and Rolph E. Anderson (1990), "Free Riding in Group Projects: Control Mechanisms and Preliminary Data," Journal of Marketing Education, (Summer), 61-67.

Tabachnick, B. G., \& Fidell, L. S. (2007). Using Multivariate Statistics. $5^{\text {th }}$ ed. Pearson Education, Inc.

Thompson \& Thornton, 2007.Exploring mental-state reasoning as a social-cognitive mechanism for social loafing in children.J Soc Psychol. 2007 Apr; 147(2):159-74. 